\title{
Correlations between the exhaust emission of dioxins, furans and PAH in gasohol and ethanol vehicles
}

\author{
R. de Abrantes ${ }^{1}$, J. V. de Assunção ${ }^{2}$ \& C. R. Pesquero ${ }^{2}$ \\ ${ }^{1}$ Vehicular Emission Laboratory, Cetesb, São Paulo, Brazil \\ ${ }^{2}$ School of Public Health, University of São Paulo, Brazil
}

\begin{abstract}
The emissions of seventeen 2,3,7,8 substituted Polychlorinated Dibenzo-pDioxins, Polychlorinated Dibenzofurans (PCDD/Fs) and sixteen Polycyclic Aromatic Hydrocarbons (PAH) [14] in the exhaust pipes of spark ignition light duty vehicles considered toxic to human health were investigated. The formations of these compounds were evaluated under the influence of variations of fuels and fuel additives.

Standard tests in a gasohol (gasohol is pure gasoline plus $20 \%$ to $25 \%$ of anhydrous ethyl alcohol fuel (AEAF)) vehicle and in an ethanol vehicle were performed with variations in the quality of fuels. The sampling of the PCDD/Fs followed the recommendations of a modified 23 method and the analysis basically followed the 8290 method. The recommendations of the TO-13 method were followed for the PAH analysis, with the necessary modifications for a vehicular emission laboratory.

The emission factors of the total PCDD/Fs varied between undetected and $0.157 \mathrm{pg} \mathrm{I-TEQ} / \mathrm{km}$. The emission factors of the total PAH varied from $0.01 \mu \mathrm{g}$ $\mathrm{TEQ} / \mathrm{km}$ to $4.61 \mu \mathrm{g} \mathrm{TEQ} / \mathrm{km}$.
\end{abstract}

Significant and positive correlations were observed between the emissions of naphthalene, acenaphthylene, fluorene, phenanthrene, anthracene and fluoranthene and significant and negative correlations were observed between the emissions of $\mathrm{CO}_{2}$ and fluoranthene in the gasohol vehicle. Significant and positive correlations between carbon monoxide and phenanthrene and between acenaphthylene, fluorene and fluoranthene in the alcohol vehicle were also observed, apart from significant and negative correlations between NOx and phenanthrene. In general way, significant correlations between $\mathrm{PAH}$ and PCDD/Fs were not observed, except in the ethanol vehicle considering phenanthrene.

Keywords: vehicular emissions, $P C D D / F s$, PAH, air pollution, toxic pollutants, gasohol, ethanol. 


\section{Introduction}

Vehicles are responsible for some pollutants that, due to their toxicities, can alter the morbidity and mortality rates of populations. The emissions of some pollutants, such as the PCDD/Fs and PAH from vehicles have the potential to cause damage to human health [9]. Some of these pollutants are carcinogenic to mammalians, even at very low concentrations $[5,16]$.

$\mathrm{PCDD} / \mathrm{Fs}$ are formed in combustion process where chlorine atoms are present. The chlorine sources for PCDD/Fs formation can be fuels and fuels additives. Small amounts of chlorine may not be removed from the fuels during refining process. Moreover, chlorine compounds can also be added to premium gasoline to improve engine performance [15].

Information about chemical composition of fuel additives is furnished in just a generic way, but it is possible that organic chlorides can be mixed with fuels additives to improve engine performance $[6,7]$; however the Brazilian Federal Administration must be informed about substances that can cause damage to human health [3].

In vehicles, PAH can be formed from incomplete fuel burning and from annealing aromatics rings. PAH emissions can also increase with vehicle aging, due to rising of lubricant oil consumption in the combustion chamber, caused by enlargement of the gaps in the engine's moving parts [10].

Considering the importance of these compounds in relation to human health, the aim of this work was to study the relations between PCDD/Fs and PAH, considered toxic to human health, in the exhaust pipe of spark ignition light duty gasohol and ethanol vehicles.

\section{Materials and methods}

\subsection{Vehicle testing conditions}

To carry out this study, two spark ignition light duty vehicles, equipped with catalytic converters and electronic injection systems, have been used, a gasohol vehicle $(\mathrm{GV})$ and a flexible fuel vehicle (EV) fuelled just with hydrated ethyl alcohol fuel (HEAF). They were representative of the vehicle fleet in the State of São Paulo, which corresponds to $36 \%$ of the Brazilian fleet [2]. The vehicles characteristics are shown in Table 1.

The assays were carried out in the vehicular emission laboratory of the State Environment Agency (Cetesb) in São Paulo, Brazil. A standardized driving cycle in a chassis dynamometer was performed [1] that simulates the urban conditions. It is identical to the American driving cycle FTP-75 procedure (USEPA).

With the purpose of establishing possible correlations between PCDD/Fs and PAH, factors that could influence the emission of these pollutants, like rate of aromatics in the fuels and fuel additives, were varied under controlled conditions, in nine assays in the GV (from G1 to G9) and six assays in the EV (from A1 to A6). All these variations compose a $2^{3-1}$ fractional factorial design, which allows determination of the influence of each variable [4]. 
Table 1: $\quad$ Vehicle characteristics.

\begin{tabular}{|c|c|c|c|c|c|c|}
\hline Year & $\begin{array}{c}\text { Mass } \\
(\mathrm{kg})\end{array}$ & $\begin{array}{c}\text { Motor } \\
(\mathrm{L})\end{array}$ & $\begin{array}{c}\text { Torque } \\
(\mathrm{k} / \mathrm{gm} \text { at } \\
\mathrm{rpm})\end{array}$ & $\begin{array}{c}\text { Power } \\
(\mathrm{kW} \text { at } \\
\mathrm{rpm})\end{array}$ & $\begin{array}{c}\text { Odometer } \\
\text { reading } \\
(\mathrm{km})\end{array}$ \\
\hline $\mathrm{GV}$ & 1998 & 1111 & 1.6 & $\begin{array}{c}15.1 \text { at } \\
4500\end{array}$ & $\begin{array}{c}78 \text { at } \\
5500\end{array}$ & 67546 \\
\hline $\mathrm{EV}$ & 2004 & 1111 & 1.6 & $\begin{array}{c}14.4 \text { at } \\
3000\end{array}$ & $\begin{array}{c}73 \text { at } \\
5750\end{array}$ & 56908 \\
\hline
\end{tabular}

\subsection{Collection and analysis}

Sampling of the exhaust gas was performed during the entire working time of the vehicle. The collection of PCDD/Fs was carried out based on a modified 23 method [13] and in the work developed by RYAN and GULLETT [8].

Raw gas was sampled through a heated line, in order to collect PCDD/Fs. Solid phase was collected in two heated $70 \mathrm{~mm}$ diameter quartz fibre filters (120 ${ }^{\circ} \mathrm{C}$ ), while the gaseous phase was collected in a cooled at $7{ }^{\circ} \mathrm{C} 60 \mathrm{~mm}$ diameter polyurethane foam (PUF), all of them assembled in series. The condensed material collected upstream the PUF was also sent for analysis. The extraction and analysis were done based in an adapted and validated 8290 method [12]. The PCDD/Fs were identified and quantified by HRGC/HRMS.

Diluted gas was sampled through a simple line, in order to collect PAH. The PAH were identified and quantified by GC/MS according an adapted TO-13 method [14]. The retention of solid phase was done by filtration; two quartz fibre filters with $47 \mathrm{~mm}$ in diameter were used, while a $22 \mathrm{~mm}$ diameter pre-washed PUF was used for retention of the gaseous phase, all of them assembled in series. Regulated pollutants were also quantified, according Brazilian legislation [1].

\section{Results and discussion}

The emissions rates of regulated pollutants obtained according Brazilian legislation, and $\mathrm{CO}_{2}$, are shown in Figure 1. The values obtained are typical of vehicles with these mileages and technology of pollutants control. In the $\mathrm{GV}$, the average emissions rates were $3.3 \mathrm{~g} / \mathrm{km}$ of carbon monoxide $(\mathrm{CO}), 0.3 \mathrm{~g} / \mathrm{km}$ of total hydrocarbons (HC), $0.5 \mathrm{~g} / \mathrm{km}$ of nitrogen oxides (NOx) and $215.8 \mathrm{~g} / \mathrm{km}$ of carbon dioxide $\left(\mathrm{CO}_{2}\right)$. In the $\mathrm{EV}$, the average emissions rates were $0.7 \mathrm{~g} / \mathrm{km}$ of $\mathrm{CO}, 0.3 \mathrm{~g} / \mathrm{km}$ of $\mathrm{HC}, 0,3 \mathrm{~g} / \mathrm{km}$ of $\mathrm{NOx}$ and $201.2 \mathrm{~g} / \mathrm{km}$ of $\mathrm{CO}_{2}$. In general way, EV emitted less regulated pollutants than GV.

The PAH emissions rates per distance travelled in the GV are shown in Figure 2. The average emissions rates were: $153.1 \mu \mathrm{g} / \mathrm{km}$ of naphthalene, 32.0 $\mu \mathrm{g} / \mathrm{km}$ of acenaphthylene, $3.5 \mu \mathrm{g} / \mathrm{km}$ of acenaphthene, $5.3 \mu \mathrm{g} / \mathrm{km}$ of fluorene, $16.3 \mu \mathrm{g} / \mathrm{km}$ of phenanthrene, $3.5 \mu \mathrm{g} / \mathrm{km}$ of anthracene, $5.9 \mu \mathrm{g} / \mathrm{km}$ of 


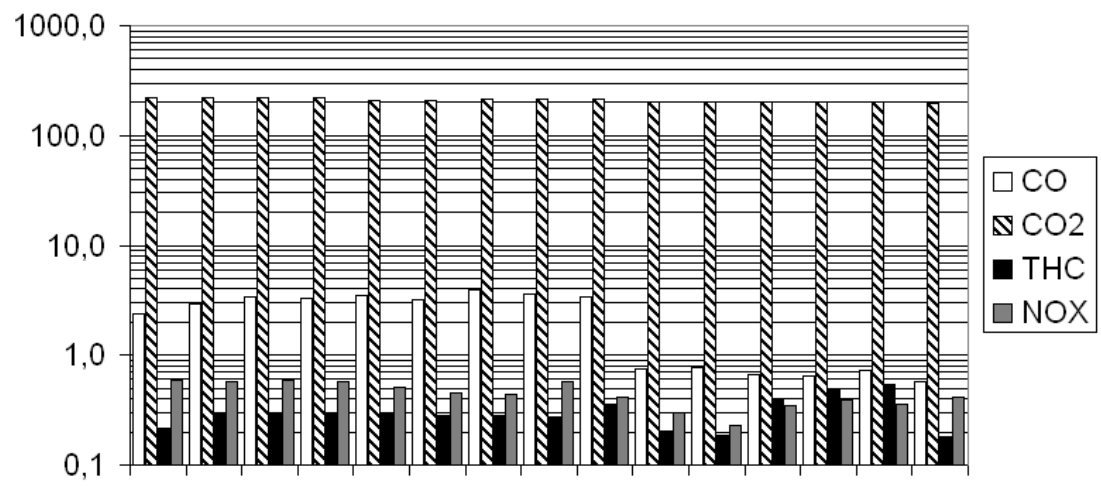

G1 G2 G3 G4 G5 G6 G7 G8 G9 A1 A2 A3 A4 A5 A6

Figure 1: Regulated pollutants emission in the vehicles, in $\mathrm{g} / \mathrm{km}$.

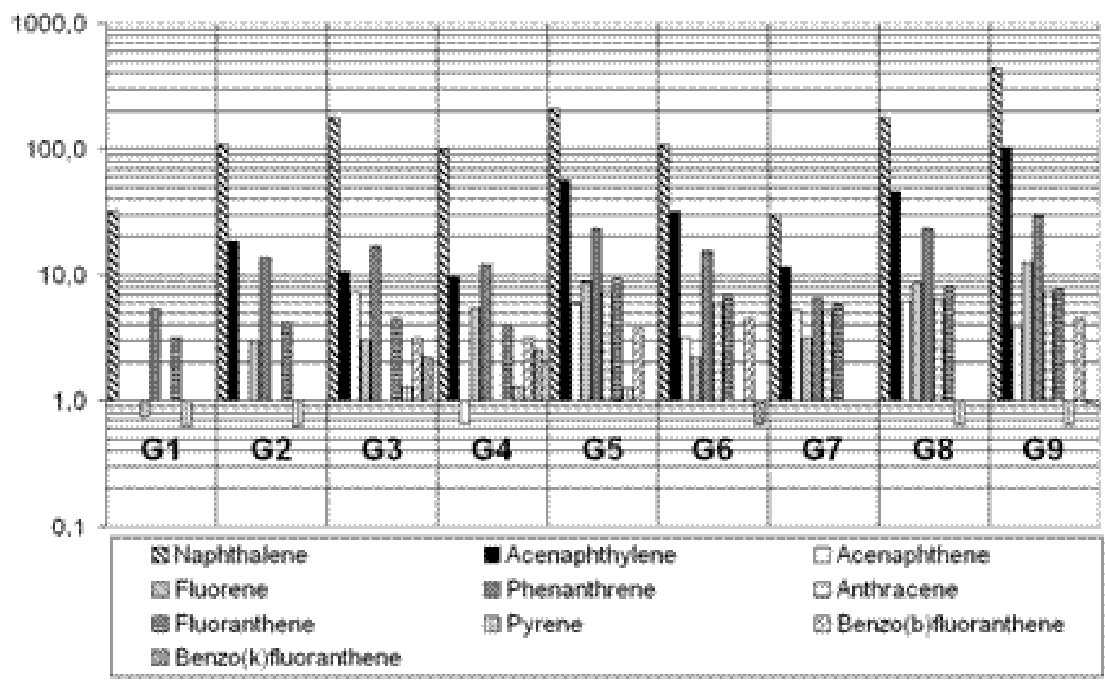

Figure 2: $\quad$ PAH Emission in the $\mathrm{GV}$, in $\mu \mathrm{g} / \mathrm{km}$.

fluoranthene, $0.7 \mu \mathrm{g} / \mathrm{km}$ of pyrene, $0.8 \mu \mathrm{g} / \mathrm{km}$ of benzo(a)anthracene, $2.1 \mu \mathrm{g} / \mathrm{km}$ of benzo(b)fluoranthene, $0.7 \mu \mathrm{g} / \mathrm{km}$ of benzo(k)fluoranthene. Benzo(a)pyrene was quantified in just one assay. chrysene, indeno(1,2,3-cd)pyrene, $\operatorname{dibenz}(\mathrm{a}, \mathrm{h})$ anthracene and benzo(g,h,i)perylene were not detected. In general way, the higher PAH molecular weight represented lower emissions rates.

The PAH emissions rates per distance travelled in the EV are shown in Figure 3. The average emissions rates were $3.0 \mu \mathrm{g} / \mathrm{km}$ of naphthalene, $2.8 \mu \mathrm{g} / \mathrm{km}$ 
of acenaphthylene, $0.9 \mu \mathrm{g} / \mathrm{km}$ of acenaphthene, $0.6 \mu \mathrm{g} / \mathrm{km}$ of fluorene, 7.7 $\mu \mathrm{g} / \mathrm{km}$ of phenanthrene, $4.0 \mu \mathrm{g} / \mathrm{km}$ of fluoranthene. Others PAH were not detected. The emission rates of PAH from EV are far lower than GV, in average $92 \%$ lesser. The PCDD/Fs emissions rates per distance travelled are shown in Figure 4. In the GV, the average emissions rates were $2.4 \mathrm{pg} / \mathrm{km}$ of $1,2,3,4,6,7,8$ Hepta Chlorinated Dibenzo-p-Dioxins (HpCDD), $16.5 \mathrm{pg} / \mathrm{km}$ of Octa Chlorinated Dibenzo-p-Dioxins (OCDD). 1,2,3,4,6,7,8 Hepta Polychlorinated Dibenzofurans (HpCDF) was quantified in just one assay. Others PCDD/Fs were not quantified, and none of the $17 \mathrm{PCDD} / \mathrm{Fs}$ studied were detected in the G8 and G9 assays. In the EV, average emissions rates were $21.2 \mathrm{pg} / \mathrm{km}$ of OCDD. HpCDD was quantified in just one assay. Others PCDD/Fs were not detected. The emissions of PCDD/Fs showed large dispersions and non-regular behaviour.

\subsection{Hierarchical cluster analysis}

This procedure attempts to identify relatively homogeneous groups of variables based on selected characteristics, using an algorithm that starts with each variable in a separate cluster and combines clusters until only one is left.

The results of samples were submitted to Hierarchical Cluster Analysis (HCA) with the intention of determine the relations between the compounds. The variables were standardized by $z$-score method, before computing the proximities, because the magnitudes of results are very different. The association levels between the pollutants were defined using the Ward's method (method of minimum variance) as measure of similarity combined with Euclidean distance.

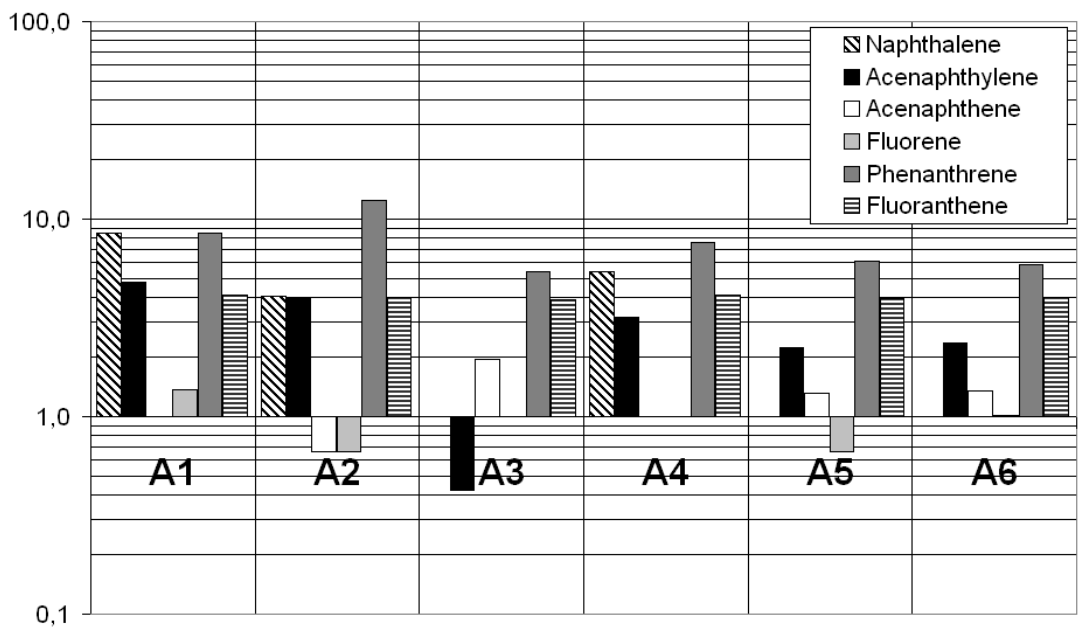

Figure 3: $\quad$ PAH emission in the $\mathrm{EV}$, in $\mu \mathrm{g} / \mathrm{km}$. 


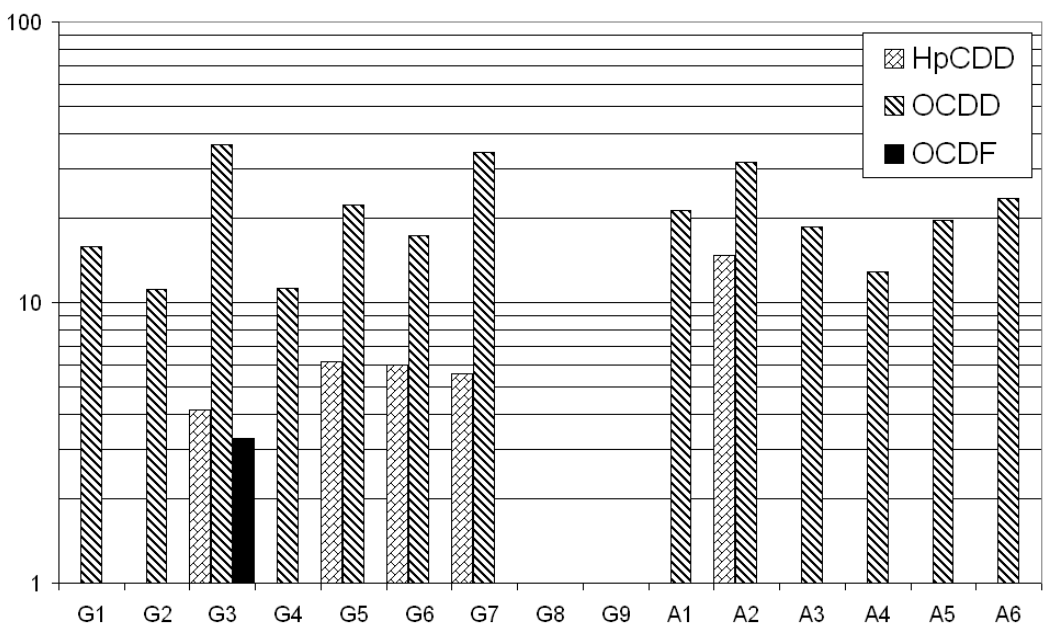

Figure 4: $\quad \mathrm{PCDD} / \mathrm{Fs}$ emission in the vehicles, in $\mathrm{pg} / \mathrm{km}$.

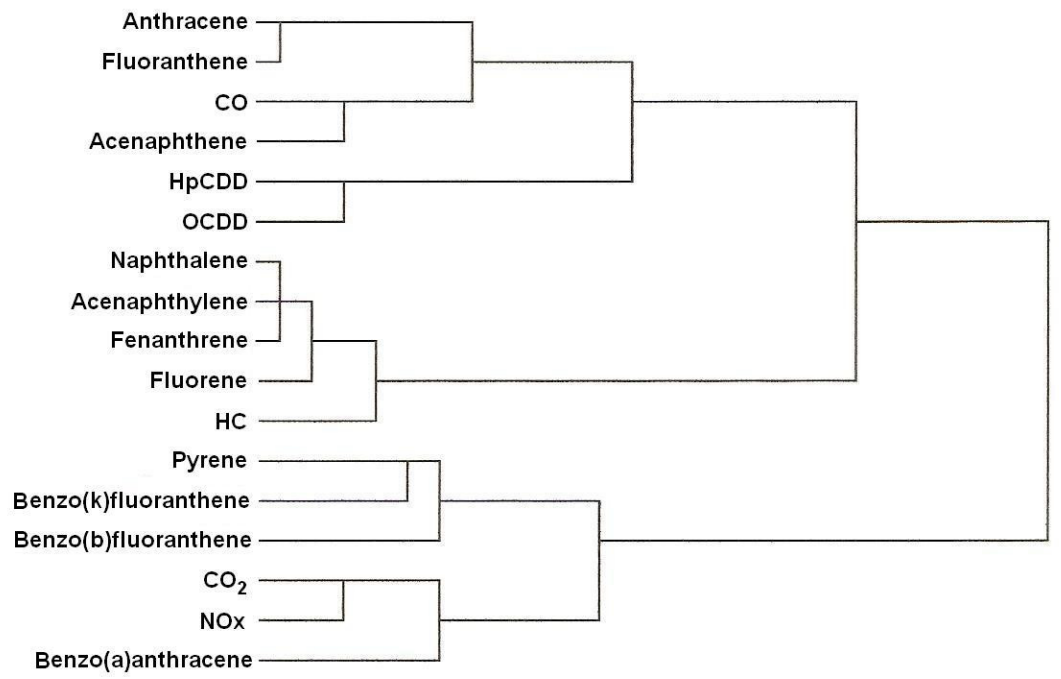

Figure 5: Dendrogram of GV obtained by Ward's method, using Euclidean distance.

The dendrogram in Figure 5 shows the results of HCA and the similarities level between the pollutants from GV. There are five groups of pollutants, the first one characterized by anthracene, fluoranthene, $\mathrm{CO}$ and acenaphthene, the correlation coefficient between them is not significant, except between 
anthracene and fluoranthene, which is 0.94 . The second is the PCDD/Fs group that does not show similarities with others compounds.

The third group shows a relationship between $\mathrm{HC}$ and naphthalene, acenaphthylene, phenanthrene and fluorene, the correlation coefficients between all of them are very significant, above 0.7 . The fourth group shows a relationship between pyrene, benzo(k)fluoranthene and benzo(b)fluoranthene, which were not detected in all assays, and the correlation coefficients are not significant. In the fifth group benzo(a)anthracene are related with $\mathrm{CO}_{2}$ and $\mathrm{NOx}$, however the correlation coefficients are also not significant. Significant and negative correlation coefficients of -0.87 are observed between the emissions of $\mathrm{CO}_{2}$ and fluoranthene.

The dendrogram in Figure 6 shows the results of HCA and the similarities level between the pollutants from EV. There are three groups of pollutants, the first one characterized by $\mathrm{CO}_{2}, \mathrm{HC}$ and $\mathrm{NOx}$ and acenaphthene, the correlation coefficients between them are not significant. In EV, HC not belongs to the light $\mathrm{PAH}$ group, because the main part of $\mathrm{HC}$ is not burned ethanol, different than occurred with GV, where the main part of $\mathrm{HC}$ is not burned gasoline.

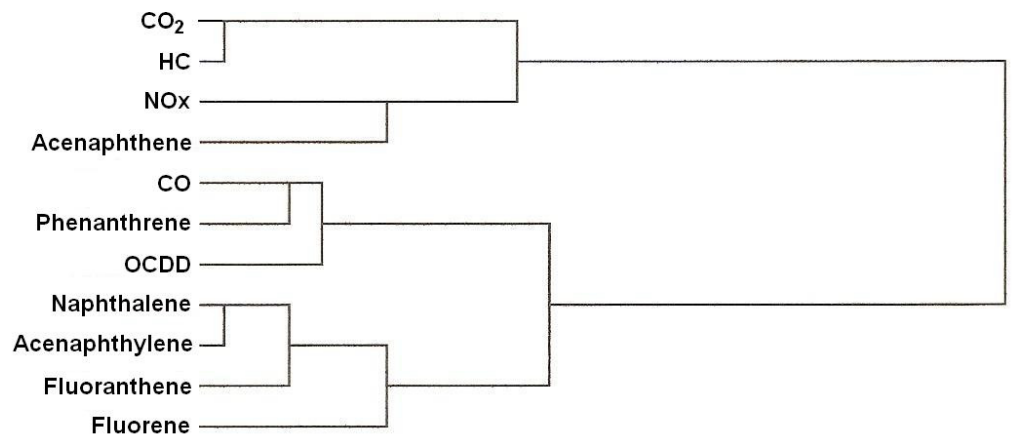

Figure 6: Dendrogram of EV obtained by Ward's method, using Euclidean distance.

Second group relates $\mathrm{CO}$, phenanthrene and OCDD. The correlation coefficients between $\mathrm{CO}$ and phenanthrene is 0.71 , and the correlation coefficients between phenanthrene and OCDD is 0.68 , indicating some relationship between then, and in certain way shows the opposite than proposed by Stanmore [11], that suggests that "de novo" formation process of PCDD/Fs was mainly proportional to the number of phenanthrene skeletons, instead annealing of aromatic rings.

The main part of $\mathrm{HC}$ in $\mathrm{GV}$ is not burned fuel, what means a phenanthrene skeletons source, however, in GV, phenanthrene and PCDD/Fs correlation is not significant, even belong the same group, according Figure 5. On the other hand, $\mathrm{PAH}$ in EV are formed predominantly by annealing process, once there are no 
aromatics in the fuel, as there is correlation between phenanthrene and OCDD, exists the possibility that PCDD/Fs are also formed mainly by annealing of aromatic rings in ethanol combustion process.

Moreover, in the second group, the correlation coefficient between $\mathrm{CO}_{2}$ and OCDD is -0.72 , and the correlation coefficient between HC and OCDD is -0.72 . The correlation coefficient between NOx and phenanthrene is -0.85 .

Third group shows a relationship between light and medium molecular weights $\mathrm{PAH}$, the correlation coefficient between acenaphthylene and fluoranthene is 0.73 and the correlation coefficient between fluorene and fluoranthene is 0.98 .

The correlation coefficient between acenaphthene and acenaphthylene is 0.98 , between acenaphthene and acenaphthylene is -0.98 and between acenaphthene and fluoranthene is -0.87 , probably the reason by acenaphthene belongs another group, according Figure 6 .

\section{Conclusions}

The two light duty vehicles used in these experiments were sources of PCDD/Fs, mainly OCDD, and PAH of light and medium molecular weight, high molecular weights $\mathrm{PAH}$ were not detected. In general way, with some exceptions, Hierarchical Cluster Analysis grouped the pollutants by their respective families, except in the case of ethanol vehicle where phenanthrene and OCDD have significant correlation coefficients, different than occurred in GV, what suggests that, in vehicles, $\mathrm{PCDD} /$ Fs are formed mainly by annealing of aromatic rings.

\section{Acknowledgements}

We want to express our gratitude to the Company of Environmental Sanitation Technology - CETESB, for the support given and to the Sao Paulo Foundation for Support to Research - FAPESP for providing the necessary financial support for this project (Grant 2004/02623-6).

\section{References}

[1] Associação brasileira de normas técnicas. NBR 6601: Veículos rodoviários automotores leves - Determinação de hidrocarbonetos, monóxido de carbono, óxidos de nitrogênio e dióxido de carbono e material particulado no gás de escapamento. (Regulation: Light self-driven vehicles: determination of hydrocarbons, carbon monoxide, nitrogen oxides, carbon dioxide and particulate matter in the exhaust pipe). Rio de Janeiro, 2005. $44 \mathrm{p}$.

[2] Associação Nacional dos Fabricantes de Veículos Automotores. Anuário estatístico da indústria automobilística brasileira 2006. (Statistical annual of the Brazilian automobile industry). [Report on line] Available at <URL: http: \www.anfavea.com.br/Index.html $>$ [accessed in 2007 jan. 26].

[3] Agência Nacional do Petróleo. Portaria n. ${ }^{\circ} 41$, de 12 de março de 1999. Establish the selling rules of automotive fuel additives and automotive additivates fuels. Diário Oficial da União. Brasília, DF, 1999 mar.15. 
[4] Bruns, R. E.; Barros Neto, B.; Scarminio, I. S. Como fazer experimentos (How to make experiments). São Paulo: Unicamp, 2006. 400 p.

[5] Kogevinas, M. Human health effects of dioxins: cancer, reproductive and endocrine system effects. Human Reproduction Update. v. 7, n. 3, p. 331-9. 2001.

[6] Lubrizol. Ready reference for lubricant and fuel performance lubricant basics - lubricant Additives. Available at <URL: http://www.lubrizol.com/ ReadyReference/LubricantBasics?lubeadditives.asp>. [Accessed in 2003 Oct. 14].

[7] Lubrizol. Lubricant properties and the role of additives. Available at <<URL: http://www.lubrizol.com/LubeTheory/prop.asp >. [Accessed in 2007 Jan. 15].

[8] Ryan e Gullett, J. R.; Gullett B. K. On-road emission sampling of heavyduty diesel vehicle for polychlorinated dibenzo-p-dioxins and polychlorinated dibenzofurans. Environmental Science \& Technology. 2000; v. 34: p. 4483-4489.

[9] Saldiva, P. H. et al. Air pollution and child mortality: a time-series study in Sao Paulo, Brazil. Environmental Health Perspectives. 109, p. 347-350, June 2001.

[10] Sher, E. (Ed). Handbook of air pollution from internal combustion engines. London: Academic Press Limited, 1998. 663 p.

[11] Stanmore, B. R. The formation of dioxins in combustion systems. Combustion and Flame. 2004; v. 136: p. 398-427.

[12] United States. Environmental Protection Agency. Method 8290: Analytical procedures and quality assurance for multimedia analysis of polychlorinated dibenzo-p-dioxins and dibenzo-p-furans by high-resolution gas chromatography/high-resolution mass spectrometry. Las Vegas: USEPA, 1994 September.

[13] United States. Environmental Protection Agency. Method 23: Determination of Polychlorinated Dibenzo-p-dioxins and Polychlorinated Dibenzofurans from Municipal Waste Combustors. USEPA, 1997. p.34

[14] United States. Environmental Protection Agency. Compendium method TO-13A - Determination of polycyclic Aromatic hydrocarbons (PAH) in ambient air using gas chromatography/mass spectrometry (CG/MS). Cincinnati: Center for environmental research information, 1999, p.78.

[15] World Health Organization. Chlorine and hydrogen chloride. Finland: 1982. 95 p. (International Programme on Chemical Safety: Environmental Health Criteria, 21).

[16] World Health Organization. Polychlorinated Dibenzo-para-dioxins and Dibenzofurans. Finland: 1989. 409 p. (International Program on Chemical Safety: Environmental Health Criteria, 88).

[17] World Health Organization. Selected non-heterocyclic polycyclic aromatic hydrocarbons. Stuttgart: 1998. 883 p. (International Programme on Chemical Safety: Environmental Health Criteria, 202). 